\title{
Choosing Promising Agbio Industry Areas by Using Fuzzy Multiple Criteria Decision Making Model
}

\author{
Yen-Ni Chang ${ }^{\mathrm{a}, 1 *}$, Chih-Young Huang ${ }^{\mathrm{a}}$, Julie Chih-Li Sun ${ }^{\mathrm{b}}$ \\ ${ }^{\mathrm{a}}$ Institute of Management of Technology, National Chiao Tung University, Hsinchu, Taiwan \\ ${ }^{\mathrm{b}}$ Biotechnology Industry Research Center, Taiwan Institute of Economic Research, Taipei, Taiwan
}

Keywords: Agricultural biotechnology, AHP, fuzzy theory, fuzzy multiple criteria decision making

Summary: Following in the wake of medical biotechnology, agricultural biotechnology (AgBio) is slated to become a key area of development in the biotechnology industry. Because agricultural biotechnology is closely connected with food, health, and resource technology industries, many countries are investing heavily in terms of both funding and talent to enhance their international competitiveness in this field. This research study was designed using the fuzzy multiple criteria decision making (FMCDM) methodology combining analytic hierarchy process (AHP) and fuzzy theory and holding a specialists' conference to decide promising AgBio products with international competitiveness for use in guiding industrial development strategies and the allocation of $R \& D$ resources. The results show that the FMCDM model can effectively summarize the views of AgBio specialists for the purpose of selecting promising target industries. The research process was also used to explore the various target industries and assess key issues such as the causal relationship between criteria and industries' degree of development. Beyond helping decision-makers formulate policies and allocate resources, this information is also provided as a research reference in connection with market surveys and industrial development trends, etc.

\section{Introduction}

Like medicine, agriculture is intimately linked with human life. The tremendous progress made in biotechnology over the last few years has led to many groundbreaking developments in agricultural biotechnology (AgBio). It is expected that AgBio will join the mainstream of biotechnology in the wake of medical biotechnology, and many countries are upbeat about this area that combines food, health, and resource sciences industries. Nevertheless, because the target industries that could be developed are many as well as vastly complex and countries have limited financial and human resources, the question of how to objectively, fairly, and effectively select and assign priority to target industries possessing international competitiveness is a very important issue. AgBio products and technologies involve both plants and animals, while subareas include agriculture, forestry, fishing, and animal husbandry. Since an industry's core competence is derived from many key factors connected with R\&D, manufacturing, mass production, and sales in the industry value chain, it is difficult to use a single criterion to assess the

\footnotetext{
1 I am especially grateful to the Taiwan Institute of Economic Research (TIER). The main sources of funding for this study's AHP questionnaire survey and specialists' conference were the NSC "National Science and Technology Program for Agricultural Biotechnology: Stage III Plan - AgBio Industrialization Strategic Plan Research Projects" research grant (Project No. NSC 93-2317-B-301-001) and a Council of Agriculture "Agricultural Biotechnology Industrialization Promotion Strategy and Promising Product Direction Analysis Program" research grant (NSC Review No. 93210117 C 040201a225000) received by TIER in 2004. I (Yen-Ni Chang) was employed concurrently with my primary position as an assistant researcher at TIER during 2004, and I was also the main research worker in charge of the aforementioned AHP questionnaire survey.

${ }^{*}$ Corresponding author. Tel: +886-912-600600, Fax: +886-3-5455603

E-mail address: yenni.mt92g@nctu.edu.tw
} 
potential of target industries. A further challenge is that appropriate scientific assessment methods must be employed to objectively evaluate all specialist views while preserving the specialists' subjective uniqueness.

This study used a fuzzy multiple criteria decision (FMCDM) model to effectively resolve the aforementioned problems. The study's goal was to assess the most promising AgBio target industries, and enable specialists in different areas to achieve a consensus and thereby evaluate the country's development priorities. The FMCDM model employed in this study was adopted from ideas proposed by Bellman and Zadeh in 1970. After many revisions, the final research design incorporated the specialist group method, use of the analytic hierarchy process (AHP) to derive criteria weights (Satty, 1977), fuzzy theory (Zadeh, 1965, 1975) and the use of multiple criteria decision making (MCDM) to evaluate and rank different alternatives (Bohanec et al, 2000). It was felt that this design provided a rigorous and objective method of analyzing the views of AgBio experts concerning potential target industries.

The results of this study show that the FMCDM model can effectively summarize the views of AgBio specialists and select the most promising target industries. The second section of this paper introduces the research method's theoretical background, the third section gives an account of the research model, the fourth section explains and discusses the research results, and the fifth section presents conclusions.

\section{Theoretical Background of Research Method}

Conventional assessment methods such as the minimum cost method, the maximum profit method and cost effectiveness analysis can be used to assess and assign priority to alternatives in simple environments or when considering only a straightforward decision-making problem. Conventional assessment methods are not appropriate means of determining a solution when the decision-making environment involves complex aspects and multiple criteria, and when there are many types of mutually-linked information (Bohanec et al, 2000; Teng and Tzeng, 1996; Tang and Tzeng, 1999) AgBio industry encompasses many fields and items, and the assessment of a particular field's potential may involve such complex aspects as technology, the industry environment, and the legal system. Because of the many criteria involved and the different perceptions of specialists in different areas, this study has employed the FMCDM method proposed by Bellman and Zadeh in 1970 to construct an FMCDM model for assessing the potential of AgBio industries.

The FMCDM model's theoretical roots include AHP and fuzzy theory. Because of this, we provide a simple introduction to these two types of research methods. AHP is a fair and objective assessment approach proposed by Prof. Saaty of the University of California in 1971. AHP is usually applied to decision-making problems involving uncertain situations and containing multiple assessment criteria. Its most notable feature is the use of a multilayer structure to systematically link influencing factors with complex mutual relationships. The pairwise comparison of factors can ease the burden on decision-makers and ensure that their intentions can be clearly expressed. Furthermore, the collective decision making process facilitates the clear and systematic integration and analysis of scholars' views, increasing the effectiveness and reliability of assessment, and presenting the results in numerical units. Beyond clarifying the relative importance and rank of different factors, AHP can also establish a weight system and apply it to resource allocation, investment portfolios, and prediction, etc. with very good effectiveness. AHP is a fair and scientific method that takes customers into consideration and reflects and summarizes specialists' opinions. In short, use of the AHP method facilities determination of the best option via the assessment of multiple criteria.

Fuzzy theory provides experts with a flexible decision-making environment. An observer often cannot assign a precise number as a score for a certain event, but can only specify a range of numbers. Taking this study as an example, not every specialist necessarily considered "very good performance" of an industry with regard to a certain criterion to be 100 points; some may have considered anything in the range of between 80 points and 100 points to be very good performance. This type of variation based on differences in individual perception is reflected in fuzzy theory. We hoped that the selection process would preserve specialists' subjective and flexible scoring of each industry, and thereby uncover the unique nature of each industry relative to different assessment criteria.

Combining AHP with the fuzzy multiple criteria decision making (FMCDM) model can enable the 
resolution of problems with multi-attribute structures. This type of problem is not amenable to decision making based on a single assessment element; problem characteristically has multiple goals or attributes, and contradictions or conflicts may exist between different criteria, or the assessment criteria are quantified in different units, or the decision-maker may have to select the optimal program from a limited number of alternatives. AHP and the FMCDM model can be applied to any problem in such areas as policy, investment portfolios, $R \& D$ product, and transportation alternatives where there are many criteria and where an alternative must be selected or an order of priority determined to meet multiple goals. Much relevant literature on this type of decision making has been published since the 1970 's, and domestic and foreign industrial research organizations used this method to determine the order of priority of R\&D plans or technological programs and thereby allocate manpower resources in the most effective manner. Based on the foregoing theoretical background of the research method, we next construct a research model for selecting the country's most promising AgBio industries.

\section{Establishment of a Research Model}

The FMCDM model's basic constituent elements consist of combinations of alternatives, combinations of criteria, the performance values resulting from the implementation of each alternative, and information on decision-makers' preferences. As a result, the model and its constituent elements had to be designed to achieve the desired goal of selecting promising AgBio industries. We first clearly defined the research goal, assessment aspects, assessment criteria, and the target industries that could be selected (the alternatives). After establishing this promote, we then performed pairwise comparison of the weights of each assessment criterion, and assigned a score to each target industry. We multiplied the scores by the weight of each criterion, and summed the performance values for all criteria. The resulting values are the overall performances of each target industry; the ranking of industries by overall performance can guide the allocation of resources. This study takes Taiwan's "National Science and Technology Program for Agricultural Biotechnology: Stage III Plan - AgBio Industrialization Strategic Plan Research Projects" as an example. The program office provided 20 target industries (alternatives) and this project hired 30 specialists from industry, government, academia, and the research community to perform selection tasks. The following is an overview of the research model framework.

After several thoroughgoing discussions, the specialists finally decided to take "industry environment," "industrialization capability," "policies and laws," and "derivative value" as the four assessment aspects (the first layer), and derived 16 assessment criteria (the second layer) from these aspects. The members of the planning committee jointly formulated 20 target industries (the third layer) that also could be regarded as niches. The research framework was as shown in the following diagram (see Fig. 1); the various assessment aspects and criteria are explained as follows:

\subsection{Industry Environment}

The assessment criteria under the aspect of "industry environment" incorporate economic factors such as Porter's "five forces" theory, up- and downstream value chains, and market supply and demand. The five assessment criteria include: (1) size of global market, (2) market maturity/degree of acceptance, (3) degree of market competition, (4) supply of upstream raw materials, and (5) domestic supply of specialist manpower.

\subsection{Industrialization Capability}

The assessment criteria under the aspect of "industrialization capability" seek to analyze the core values (which may consist of flagship products, key technologies, platforms or integration systems) of the industry in question, and take into consideration all elements from $\mathrm{R} \& \mathrm{D}$, manufacturing, mass production through marketing, while incorporating the concept of cost. These criteria therefore include (1) domestic R\&D/innovation ability, (2) domestic mass production capability, (3) domestic production cost competitiveness, and (4) marketing channel capability. 
Fig. 1. Structure of AHP Model for Selecting Promising AgBio Industries

$\begin{array}{ccc} & \text { Layer 1: } & \text { Layer 2: } \\ \text { Goal } & \text { Assessment aspects } & \text { Assessment criteria }\end{array}$

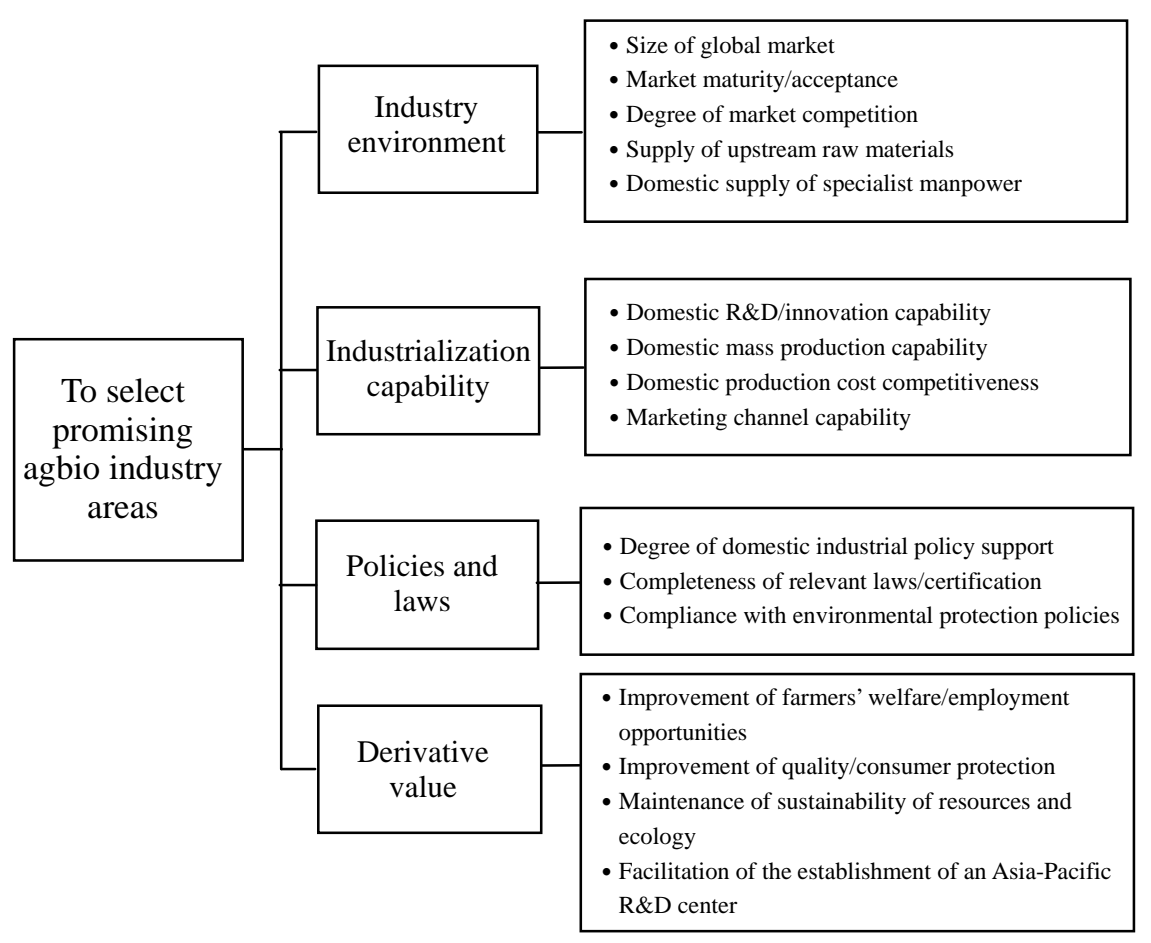

Layer 3:

Target industries (niche items)
1. Development and integration of a flower (orchid) production-marketing system

2. Development and integration of a flower (chrysanthemum) production-marketing system

3. Development of biological agents (for plant use)

4. Development of biological agents (for animal use)

5. Development of superior shrimp larvae and transport/sales technology R\&D

6. Development of superior fish fry (porgy and grouper) and transport/sales technology R\&D

7. R\&D on biotech in globalization of Taiwan tilapia culture

8. Biotech in cobia cage culture aquaculture and improvement of processing technology

9. Integration and industrial application of fruit/vegetable/flower freshness preservation techniques (recombinant DNA technology)

10. Integration and industrial application of fruit/vegetable/flower freshness preservation techniques (conventional technology)

11. Application of transgenic technology to non-food plants/animals and feeds

12. Superior rice $R \& D$ and establishment of a certification system

13. Development of an agricultural molecular testing system

14. Development of technology connected with bioreactors for producing special purpose products

15. Recycling of agricultural waste

16. Integration of organismic agriculture production standards and key technologies (anti-stress strains, biological pesticides, and biological fertilizers)

17. Investigation of key technologies for upgrading the Oolong tea industry

18. Promotion and establishment of a Chinese herbal medicine and health food industrialization system

19. Upgrading of the superior hog and chicken production systems

\subsection{Policies and Laws}

The assessment criteria under the aspect of "policies and laws" primarily address factors that may assist the growth of the industry in question, and seek to determine whether there is policy support, whether laws and regulations are comprehensive, and whether there may be violation of environmental protection principles. Assessment criteria include (1) degree of domestic industrial policy support, (2) completeness of relevant laws/certification, and (3) compliance with environmental protection policies.

\subsection{Derivative Value}

The assessment criteria under the aspect of "derivative value" primarily examine the social benefit brought by the industry in question, such as whether it promotes farmers' welfare and increases employment, whether the products increase safety, and whether the industry contributes to making Taiwan an Asia-Pacific AgBio R\&D center. Assessment criteria include (1) improvement of farmers' welfare/employment opportunities, (2) improvement of quality/consumer protection, (3) maintenance of sustainability of resources and ecology, and (4) facilitation of the establishment of an Asia-Pacific R\&D center.

To preserve the specialists' subjective scoring of each industry with relation to the foregoing criteria, we gave the specialists five performance levels (very good, good, average, poor, very poor) with which to score each criterion. We also allocated them to set upper and lower limits, which was necessary to facilitate our subsequent calculation of each industry's performance value. We used the Expert Choice Pro 9.5 software package to process the questionnaire data, including calculation of the FMCDM 
model's priority vector, consistency index, consistency ratio, and overall layer weight. We also employed Microsoft's Excel XP spreadsheet software to calculate the weight assigned to each assessment criteria by each specialist and the overall performance value of each target industry.

\section{Selection Results and Discussion}

After formulating the assessment goal, assessment aspects, assessment criteria, and target industries (alternatives) as described above, we asked the members of the planning committee to fill out questionnaires. A total of 28 questionnaires were returned, and an inspection of the specialists' degree of familiarity (average familiarity was 76.96\%) was employed to confirm the committee members' ability to professionally assess the target industries.

\subsection{Weighting of Assessment Aspects and Criteria}

The results of the questionnaire survey (Table 1) indicate that the members of the specialist committee felt that "marketing channel capability" (10.82\%)was the leading factor distinguishing promising industries, and this was followed by "R\&D innovation ability"(10.25\%), "completeness of relevant laws/certification "(9.94\%), and "degree of domestic industrial policy support"(8.28\%). This shows that the members of the specialists committee placed a relatively high degree of emphasis on the two assessment aspects of "industrialization capability"(31.65\%) and "policies and laws" (25.46\%).

Table 1 Weights Assigned to AgBio Target Industry Assessment Criteria

\begin{tabular}{|c|c|c|c|}
\hline Assessment aspect & Assessment criteria & Weight percentage & Rank \\
\hline \multirow{6}{*}{ Industry environment } & & $21.54 \%(3)$ & \\
\hline & Size of global market & $3.75 \%$ & $(16)$ \\
\hline & Market maturity/acceptance & $4.16 \%$ & (15) \\
\hline & Degree of market competition & $4.24 \%$ & (14) \\
\hline & Supply of upstream raw materials & $4.67 \%$ & $(12)$ \\
\hline & Domestic supply of specialist manpower & $5.08 \%$ & (9) \\
\hline \multirow{5}{*}{$\begin{array}{l}\text { Industrialization } \\
\text { capability }\end{array}$} & & $31.65 \%(1)$ & \\
\hline & Domestic R\&D/innovation capability & $10.25 \%$ & $(2)$ \\
\hline & Domestic mass production capability & $4.28 \%$ & (13) \\
\hline & Domestic production cost competitiveness & $6.80 \%$ & (5) \\
\hline & Marketing channel capability & $10.82 \%$ & (1) \\
\hline \multirow[t]{4}{*}{ Policies and laws } & & $25.46 \%(2)$ & \\
\hline & Degree of domestic industrial policy support & $8.28 \%$ & (4) \\
\hline & Completeness of relevant laws/certification & $9.94 \%$ & (3) \\
\hline & $\begin{array}{l}\text { Compliance with environmental protection } \\
\text { policies }\end{array}$ & $6.08 \%$ & (6) \\
\hline \multirow[t]{5}{*}{ Derivative value } & & $21.35 \%(4)$ & \\
\hline & $\begin{array}{l}\text { Improvement of farmers' welfare/employment } \\
\text { opportunities }\end{array}$ & $4.84 \%$ & $(10)$ \\
\hline & Improvement of quality/consumer protection & $6.05 \%$ & (7) \\
\hline & $\begin{array}{l}\text { Maintenance of sustainability of resources and } \\
\text { ecology }\end{array}$ & $5.96 \%$ & (8) \\
\hline & $\begin{array}{l}\text { Facilitation of the establishment of an } \\
\text { Asia-Pacific R\&D center }\end{array}$ & $4.82 \%$ & (11) \\
\hline
\end{tabular}

\subsection{Results of Comparing Promising AgBio Industries}

After multiplying "assessment criteria weight" by "performance value" and summing the scores assigned by all committee members, the target industries were ranked as shown in Table 2. The joint specialists' selection process yielded a list of the five most promising industries. These were, in order, development and integration of an orchid production-marketing system (73.61), R\&D on biotech in globalization of Taiwan tilapia culture (69.66), development of superior shrimp larvae and transport/sales technology R\&D (68.95), promotion and establishment of a Chinese herbal medicine and health food 
industrialization system (68.67), and development and integration of a chrysanthemum production-marketing system (67.26). There was an even distribution of plant and animal items among the top ten industries, each accounting for $50 \%$.

Table 2 Rank of Promising AgBio Industries

\begin{tabular}{clc}
\hline Rank & Promising target industries & Score \\
\hline 1 & Orchids & 73.61 \\
2 & Taiwan Tilapia & 69.66 \\
3 & Shrimp larvae & 68.95 \\
4 & Chinese herbal medicines & 68.67 \\
5 & Chrysanthemums & 67.26 \\
6 & Cobia aquaculture & 66.91 \\
7 & Fish fry (porgy and grouper) & 66.46 \\
8 & Superior hogs and chickens & 65.82 \\
9 & Fruit and vegetable freshness preservation (conventional technology) & 65.64 \\
10 & Superior rice & 65.59 \\
11 & Oolong tea & 65.52 \\
12 & Organismic agriculture & 64.12 \\
13 & Biological agents (for animal use) & 62.84 \\
14 & Biological agents (for plant use) & 62.18 \\
15 & Agricultural molecular testing & 61.71 \\
16 & Waste recycling & 60.92 \\
17 & Fruit and vegetable freshness preservation (recombinant DNA technology) & 58.54 \\
18 & GMO & 57.66 \\
19 & Bioreactors & 57.55 \\
20 & Transgenic technology & 56.25 \\
\hline
\end{tabular}

Note: This table abbreviates the names of the industries; for instance, "development and integration of an orchid production-marketing system" is simplified as "orchids."

\subsection{Analysis of High and Low Performance Criteria for Each Target Industry}

In accordance with the assessment scores that each planning committee member gave to the criteria for each industry, each criterion was evaluated as either "high performance" (cumulative performance was very good or good) or is "low performance" (cumulative performance was very poor or poor). When the scoring results for all committee members were summed, the top three high performance criteria and bottom three low performance criteria for each industry were found to be as shown in tables 3 and 4; this information may serve to guide future development strategy decisions.

"Derivative value" was the most common highest criterion among the top three criteria for each industry. "Industry environment" was second, and "industrialization capability" and "policies and laws" were tied for third place. "Laws/certification" was the worst of the low performance criteria for 19 industries, however, which indicates that the members of the specialists committee consistently felt that the development of AgBio industry in Taiwan will require the strengthened planning of legal and certification systems.

\subsection{Rank of Target Industries for Each Assessment Criterion}

The members of the planning committee assigned a score to each industry relative to each criterion. Table 5 shows the top industries for each criterion in terms of their performance. We found that "orchids," "Chinese herbal medicine/health foods," "superior seedlings," "cobia cage aquaculture," "Taiwan tilapia," and "fruit and vegetable freshness preservation technology" had relatively good performance relative to all criteria. This information can provide decision-makers with another angle for thinking about development priorities, and can be used for strategic planning and analysis in conjunction with the selection results derived using the FMCDM model. 


\section{Table 3 Top Three "high performance" Criteria for Each Industry}

\begin{tabular}{|c|c|c|c|c|c|c|}
\hline \multirow{2}{*}{ Target industry } & \multicolumn{6}{|c|}{ Three criteria with highest performance } \\
\hline & First criterion & Score & Second criterion & Score & Third criterion & Score \\
\hline Orchid production-marketing system & Size of market & 7.407 & Market maturity & 7.037 & R\&D capability & 7.037 \\
\hline Chrysanthemum production-marketing system & Market maturity & 4.815 & Asia-Pacific center & 4.815 & Raw materials supply & 4.630 \\
\hline Biological agents (for plant use) & Maintenance of resources & 4.615 & Environmental protection & 4.423 & Quality improvement & 4.423 \\
\hline Biological agents (for animal use) & Size of market & 4.800 & Quality improvement & 4.200 & Industrial policy & 4.000 \\
\hline Shrimp larvae & Asia-Pacific center & 6.458 & Size of market & 6.250 & Quality improvement & 6.042 \\
\hline Fish fry (porgy and grouper) & Asia-Pacific center & 5.652 & Quality improvement & 5.435 & Raw materials supply & 4.783 \\
\hline Tilapia globalization & Industrial policy & 5.625 & Mass production capability & 5.417 & Farmers' welfare & 5.208 \\
\hline Cobia cage aquaculture & Size of market & 5.208 & Asia-Pacific center & 5.208 & Quality improvement & 5.000 \\
\hline Fruit and vegetable freshness preservation (recombinant DNA) & Mass production capability & 5.800 & Asia-Pacific center & 4.800 & Farmers' welfare & 4.200 \\
\hline Fruit and vegetable freshness preservation (conventional) & Farmers' welfare & 5.385 & Quality improvement & 4.808 & Size of market & 4.231 \\
\hline Use of transgenic technology in animal feed & Asia-Pacific center & 3.846 & R\&D capability & 3.269 & Size of market & 3.077 \\
\hline Superior rice & Quality improvement & 6.000 & Farmers' welfare & 5.200 & R\&D capability & 4.600 \\
\hline Agricultural molecular testing system & Asia-Pacific center & 4.423 & Size of market & 4.231 & Quality improvement & 4.231 \\
\hline Bioreactors & Asia-Pacific center & 5.000 & Size of market & 4.038 & Quality improvement & 3.462 \\
\hline Agricultural waste recycling & Environmental protection & 5.370 & Maintenance of resources & 5.370 & Quality improvement & 3.519 \\
\hline Organismic agriculture & Maintenance of resources & 5.769 & Quality improvement & 5.000 & Environmental protection & 4.615 \\
\hline Oolong tea industry upgrading & Quality improvement & 5.870 & Industrial policy & 5.652 & Asia-Pacific center & 5.217 \\
\hline Chinese herbal medicine and health foods & Size of market & 6,731 & Asia-Pacific center & 6.154 & Market maturity & 5.962 \\
\hline Superior hog and chicken production system & Quality improvement & 5.833 & Asia-Pacific center & 5.417 & Farmers' welfare & 4.792 \\
\hline GMO assessment technology \& certification & Asia-Pacific center & 5.370 & Quality improvement & 5.185 & Size of market & 3.333 \\
\hline
\end{tabular}


Table 4 Bottom Three "high performance" Criteria for Each Industry

\begin{tabular}{|c|c|c|c|c|c|c|}
\hline \multirow{2}{*}{ Target industry } & \multicolumn{6}{|c|}{ Three criteria with worst performance } \\
\hline & Worst criterion & Score & Second worst criterion & Score & Third worst criterion & Score \\
\hline Orchid production-marketing system & Laws/certification & 1.111 & Production cost & 0.370 & Industrial policy & 0.370 \\
\hline Chrysanthemum production-marketing system & Laws/certification & 1.296 & Industrial policy & 0.556 & Environmental protection & 0.556 \\
\hline Biological agents (for plant use) & Laws/certification & 2.692 & Market competition & 1.154 & Marketing channels & 0.962 \\
\hline Biological agents (for animal use) & Laws/certification & 2.200 & Mass production capability & 1.000 & Marketing channels & 1.000 \\
\hline Shrimp larvae & Laws/certification & 1.458 & Raw materials supply & 0.625 & Environmental protection & 0.625 \\
\hline Fish fry (porgy and grouper) & Laws/certification & 1.522 & Environmental protection & 0.652 & Maintenance of resources & 0.652 \\
\hline Tilapia globalization & Laws/certification & 1.458 & Production cost & 0.625 & Environmental protection & 0.625 \\
\hline Cobia cage aquaculture & Laws/certification & 1.667 & Maintenance of resources & 0.833 & Environmental protection & 0.625 \\
\hline Fruit and vegetable freshness preservation (recombinant DNA) & Laws/certification & 3.600 & Marketing channels & 1.600 & Industrial policy & 1.400 \\
\hline Fruit and vegetable freshness preservation (conventional) & Laws/certification & 1.538 & Market competition & 0.962 & Production cost & 0.769 \\
\hline Use of transgenic technology in animal feed & Laws/certification & 4.808 & Marketing channels & 2.500 & Market maturity & 1.538 \\
\hline Superior rice & Laws/certification & 1.600 & Production cost & 1.200 & Size of market & 1.000 \\
\hline Agricultural molecular testing system & Laws/certification & 2.692 & Market maturity & 1.154 & Production cost & 1.154 \\
\hline Bioreactors & Laws/certification & 3.462 & Market competition & 2.115 & Market maturity & 1.923 \\
\hline Agricultural waste recycling & Marketing channels & 2.407 & Laws/certification & 1.852 & Size of market & 1.667 \\
\hline Organismic agriculture & Laws/certification & 1.731 & Marketing channels & 0.962 & Market competition & 0.577 \\
\hline Oolong tea industry upgrading & Laws/certification & 2.174 & Environmental protection & 1.087 & Maintenance of resources & 1.087 \\
\hline Chinese herbal medicine and health foods & Laws/certification & 1.731 & Production cost & 0.769 & Raw materials supply & 0.577 \\
\hline Superior hog and chicken production system & Laws/certification & 1.458 & Production cost & 1.042 & Environmental protection & 1.042 \\
\hline GMO assessment technology \& certification & Laws/certification & 4.630 & Market competition & 1.852 & Market maturity & 1.852 \\
\hline
\end{tabular}


Table 5 Industry Rank for Each Assessment Criterion

\begin{tabular}{|c|c|c|c|c|}
\hline Rank & Size of global market & Market maturity/acceptance & Degree of market competition & Supply of upstream raw materials \\
\hline 1 & Orchids & Orchids & Chinese herbal medicines/health food & Orchids \\
\hline 2 & Chinese herbal medicines/health food & Shrimp larvae & Orchids & Taiwan tilapia \\
\hline 3 & Shrimp larvae & Chinese herbal medicines/health food & Taiwan tilapia & Fish fry (porgy and grouper) \\
\hline 4 & Cobia & Chrysanthemums & Fish fry (porgy and grouper) & Chrysanthemums \\
\hline 5 & Biological agents (for animal use) & Cobia & Shrimp larvae & Chinese herbal medicines/health food \\
\hline 6 & Fish fry (porgy and grouper) & Taiwan tilapia & Cobia & Cobia \\
\hline 7 & $\begin{array}{l}\text { Fruit/vegetable freshness preservation } \\
\text { (conventional technology)* }\end{array}$ & $\begin{array}{l}\text { Fruit/vegetable freshness preservation } \\
\text { (conventional technology) }\end{array}$ & $\begin{array}{l}\text { Fruit/vegetable freshness preservation } \\
\text { (conventional technology) }\end{array}$ & Oolong tea \\
\hline 8 & Agricultural molecular testing* & Fish fry (porgy and grouper) & $\begin{array}{l}\text { Fruit/vegetable freshness preservation } \\
\text { (recombinant DNA technology) }\end{array}$ & Biological agents (for animal use) \\
\hline 9 & Bioreactors & Superior hogs and chickens & Organismic agriculture & Shrimp larvae \\
\hline 10 & $\begin{array}{l}\text { Fruit/vegetable freshness preservation } \\
\text { (recombinant DNA technology) }\end{array}$ & Biological agents (for plant use) & Oolong tea & $\begin{array}{l}\text { Fruit/vegetable freshness preservation } \\
\text { (conventional technology) }\end{array}$ \\
\hline 11 & Biological agents (for plant use) & Superior rice & Superior rice & Superior hogs and chickens \\
\hline 12 & Taiwan tilapia** & Biological agents (for animal use) & Superior hogs and chickens & Biological agents (for plant use) \\
\hline 13 & Superior hogs and chickens** & Agricultural molecular testing & Transgenic technology & Superior rice \\
\hline 14 & GMO & Organismic agriculture & Agricultural molecular testing* & Waste recycling \\
\hline 15 & Organismic agriculture & $\begin{array}{l}\text { Fruit/vegetable freshness preservation } \\
\text { (recombinant DNA technology) }\end{array}$ & Bioreactors* & Agricultural molecular testing \\
\hline 16 & Chrysanthemums & Oolong tea & Biological agents (for animal use) & Transgenic technology* \\
\hline 17 & Transgenic technology & Bioreactors & Chrysanthemums & Organismic agriculture* \\
\hline 18 & Superior rice & GMO & Biological agents (for plant use) & $\begin{array}{l}\text { Fruit/vegetable freshness preservation } \\
\text { (recombinant DNA technology) }\end{array}$ \\
\hline 19 & Oolong tea & Waste recycling & GMO & Bioreactors \\
\hline 20 & Waste recycling & Transgenic technology & Waste recycling & GMO \\
\hline
\end{tabular}

Note: $*, * *$, and $* * *$ indicate that the adjacent industries had identical scores relative the assessment criterion in question.

(continued on next page) 
Table 5 Industry Rank for Each Assessment Criterion (continued)

\begin{tabular}{|c|c|c|c|c|}
\hline Rank & Domestic supply of specialist manpowe & Domestic R\&D/innovation capability & Domestic mass production capability & $\begin{array}{l}\text { Domestic production cost } \\
\text { competitiveness }\end{array}$ \\
\hline 1 & Orchids & Orchids & Orchids & Orchids \\
\hline 2 & Chinese herbal medicines/health food & Shrimp larvae & $\begin{array}{l}\text { Fruit/vegetable freshness preservation } \\
\text { (recombinant DNA technology) }\end{array}$ & Taiwan tilapia \\
\hline 3 & Shrimp larvae & Chrysanthemums & Taiwan tilapia & Cobia \\
\hline 4 & Cobia & Chinese herbal medicines/health food & Chrysanthemums & Chinese herbal medicines/health food \\
\hline 5 & Chrysanthemums & Superior rice & Shrimp larvae & Shrimp larvae \\
\hline 6 & Superior hogs and chickens* & Taiwan tilapia* & Chinese herbal medicines/health food & Chrysanthemums \\
\hline 7 & Taiwan tilapia* & Cobia* & Cobia & Fish fry (porgy and grouper) \\
\hline 8 & Superior rice & Fish fry (porgy and grouper) & Fish fry (porgy and grouper) & Oolong tea \\
\hline 9 & Fish fry (porgy and grouper) & Agricultural molecular testing & Superior hogs and chickens & Bioreactors \\
\hline 10 & Agricultural molecular testing & Superior hogs and chickens & Oolong tea & Biological agents (for animal use) \\
\hline 11 & Oolong tea & Oolong tea & Superior rice & Biological agents (for plant use) \\
\hline 12 & $\begin{array}{l}\text { Fruit/vegetable freshness preservation } \\
\text { (conventional technology)** }\end{array}$ & $\begin{array}{l}\text { Fruit/vegetable freshness preservation } \\
\text { (recombinant DNA technology) }\end{array}$ & Biological agents (for animal use) & Agricultural molecular testing \\
\hline 13 & Transgenic technology** & Transgenic technology & Bioreactors* & Superior hogs and chickens \\
\hline 14 & $\begin{array}{l}\text { Fruit/vegetable freshness preservation } \\
\text { (recombinant DNA technology) }\end{array}$ & $\begin{array}{l}\text { Fruit/vegetable freshness preservation } \\
\text { (conventional technology) }\end{array}$ & Organismic agriculture* & Transgenic technology* \\
\hline 15 & Waste recycling & Biological agents (for animal use) & Biological agents (for plant use)** & Organismic agriculture* \\
\hline 16 & Bioreactors & Biological agents (for plant use) & Agricultural molecular testing** & $\begin{array}{l}\text { Fruit/vegetable freshness preservation } \\
\text { (recombinant DNA technology)** }\end{array}$ \\
\hline 17 & Biological agents (for animal use) & Bioreactors & $\begin{array}{l}\text { Fruit/vegetable freshness preservation } \\
\text { (conventional technology)*** }\end{array}$ & Superior rice** \\
\hline 18 & Organismic agriculture & Organismic agriculture & Transgenic technology*** & GMO \\
\hline 19 & Biological agents (for plant use) & Waste recycling & Waste recycling & $\begin{array}{l}\text { Fruit/vegetable freshness preservation } \\
\text { (conventional technology) }\end{array}$ \\
\hline 20 & GMO & GMO & GMO & Waste recycling \\
\hline
\end{tabular}

Note: $*$, **, and $* * *$ indicate that the adjacent industries had identical scores relative the assessment criterion in question.

(continued on next page) 
Table 5 Industry Rank for Each Assessment Criterion (continued)

\begin{tabular}{|c|c|c|c|c|}
\hline Rank & Marking channel capability & $\begin{array}{l}\text { Degree of domestic industrial policy } \\
\text { support }\end{array}$ & $\begin{array}{l}\text { Completeness of relevant } \\
\text { laws/certification }\end{array}$ & $\begin{array}{l}\text { Compliance with environmental } \\
\text { protection policies }\end{array}$ \\
\hline 1 & Orchids & Orchids & Oolong tea & Waste recycling \\
\hline 2 & Shrimp larvae* & Chinese herbal medicines/health food & $\begin{array}{l}\text { Fruit/vegetable freshness preservation } \\
\text { (conventional technology) }\end{array}$ & Orchids \\
\hline 3 & Taiwan tilapia* & Oolong tea & Shrimp larvae* & Organismic agriculture \\
\hline 4 & Oolong tea & Taiwan tilapia & Superior hogs and chickens* & Biological agents (for plant use) \\
\hline 5 & Chinese herbal medicines/health food & Chrysanthemums & Chinese herbal medicines/health food & Biological agents (for animal use) \\
\hline 6 & Superior hogs and chickens & Superior rice & Chrysanthemums & Shrimp larvae \\
\hline 7 & Cobia & Cobia* & Orchids & Chrysanthemums \\
\hline 8 & Fish fry (porgy and grouper) & Shrimp larvae* & Superior rice & Agricultural molecular testing* \\
\hline 9 & Chrysanthemums & Superior hogs and chickens & Taiwan tilapia** & Chinese herbal medicines/health food* \\
\hline 10 & Superior rice & Fish fry (porgy and grouper) & Cobia** & Cobia \\
\hline 11 & $\begin{array}{l}\text { Fruit/vegetable freshness preservation } \\
\text { (conventional technology) }\end{array}$ & Biological agents (for animal use) & Biological agents (for animal use) & Superior rice \\
\hline 12 & Transgenic technology & Organismic agriculture & Waste recycling & $\begin{array}{l}\text { Fruit/vegetable freshness preservation } \\
\text { (conventional technology) }\end{array}$ \\
\hline 13 & Biological agents (for animal use) & Waste recycling** & $\begin{array}{l}\text { Fruit/vegetable freshness preservation } \\
\text { (recombinant DNA technology) }\end{array}$ & Taiwan tilapia \\
\hline 14 & Bioreactors & $\mathrm{GMO}^{* *}$ & Biological agents (for plant use) & GMO \\
\hline 15 & $\begin{array}{l}\text { Fruit/vegetable freshness preservation } \\
\text { (recombinant DNA technology) }\end{array}$ & Biological agents (for plant use) & Fish fry (porgy and grouper) & Fish fry (porgy and grouper)** \\
\hline 16 & Agricultural molecular testing** & Agricultural molecular testing & Organismic agriculture & Oolong tea** \\
\hline 17 & Organismic agriculture $* *$ & $\begin{array}{l}\text { Fruit/vegetable freshness preservation } \\
\text { (recombinant DNA technology) }\end{array}$ & Transgenic technology*** & Bioreactors \\
\hline 18 & Biological agents (for plant use) & $\begin{array}{l}\text { Fruit/vegetable freshness preservation } \\
\text { (conventional technology) }\end{array}$ & Agricultural molecular testing*** & $\begin{array}{l}\text { Fruit/vegetable freshness preservation } \\
\text { (recombinant DNA technology) }\end{array}$ \\
\hline 19 & Waste recycling*** & Bioreactors & GMO & Superior hogs and chickens \\
\hline 20 & $\mathrm{GMO}^{* * *}$ & Transgenic technology & Bioreactors & Transgenic technology \\
\hline
\end{tabular}

Note: ${ }^{* * *}$, and $* * *$ indicate that the adjacent industries had identical scores relative the assessment criterion in question.

(continued on next page) 
Table 5 Industry Rank for Each Assessment Criterion (continued)

\begin{tabular}{|c|c|c|c|c|}
\hline Rank & $\begin{array}{l}\text { Improvement of farmers' } \\
\text { welfare/employment opportunities }\end{array}$ & $\begin{array}{l}\text { Improvement of quality/consumer } \\
\text { protection }\end{array}$ & $\begin{array}{l}\text { Maintenance of sustainability of } \\
\text { resources and ecology }\end{array}$ & $\begin{array}{l}\text { Facilitation of the establishment of an } \\
\text { Asia-Pacific R\&D center }\end{array}$ \\
\hline 1 & $\begin{array}{l}\text { Fruit/vegetable freshness preservation } \\
\text { (conventional technology) }\end{array}$ & Shrimp larvae & Organismic agriculture & Orchids \\
\hline 2 & Orchids & Superior rice & Waste recycling & Shrimp larvae \\
\hline 3 & Taiwan tilapia & Chinese herbal medicines/health food & Biological agents (for plant use) & Chinese herbal medicines/health food \\
\hline 4 & Superior rice & Oolong tea & Biological agents (for animal use) & Fish fry (porgy and grouper) \\
\hline 5 & Shrimp larvae & Superior hogs and chickens & Orchids & Superior hogs and chickens \\
\hline 6 & Cobia* & Fish fry (porgy and grouper) & Agricultural molecular testing & GMO \\
\hline 7 & Superior hogs and chickens* & Taiwan tilapia & GMO & Oolong tea \\
\hline 8 & Fish fry (porgy and grouper) & GMO & Superior rice & Cobia* \\
\hline 9 & Chrysanthemums & Orchids* & Chrysanthemums & Taiwan tilapia* \\
\hline 10 & Chinese herbal medicines/health food & Cobia* & $\begin{array}{l}\text { Fruit/vegetable freshness preservation } \\
\text { (conventional technology)* }\end{array}$ & Bioreactors \\
\hline 11 & Oolong tea & Organismic agriculture* & Chinese herbal medicines/health food* & Chrysanthemums \\
\hline 12 & $\begin{array}{l}\text { Fruit/vegetable freshness preservation } \\
\text { (recombinant DNA technology) }\end{array}$ & $\begin{array}{l}\text { Fruit/vegetable freshness preservation } \\
\text { (conventional technology) }\end{array}$ & Fish fry (porgy and grouper) & $\begin{array}{l}\text { Fruit/vegetable freshness preservation } \\
\text { (recombinant DNA technology) }\end{array}$ \\
\hline 13 & Organismic agriculture & Biological agents (for plant use) & Shrimp larvae** & Agricultural molecular testing \\
\hline 14 & Waste recycling & Agricultural molecular testing & Taiwan tilapia** & $\begin{array}{l}\text { Fruit/vegetable freshness preservation } \\
\text { (conventional technology) }\end{array}$ \\
\hline 15 & Transgenic technology & Biological agents (for animal use) & Bioreactors & Biological agents (for plant use)** \\
\hline 16 & Biological agents (for animal use) & $\begin{array}{l}\text { Fruit/vegetable freshness preservation } \\
\text { (recombinant DNA technology) }\end{array}$ & Cobia*** & Transgenic technology** \\
\hline 17 & Biological agents (for plant use) & Chrysanthemums & Superior hogs and chickens*** & Organismic agriculture** \\
\hline 18 & Agricultural molecular testing & Waste recycling & $\begin{array}{l}\text { Fruit/vegetable freshness preservation } \\
\text { (recombinant DNA technology) }\end{array}$ & Biological agents (for animal use) \\
\hline 19 & Bioreactors & Bioreactors & Oolong tea & Waste recycling \\
\hline 20 & GMO & Transgenic technology & Transgenic technology & Superior rice \\
\hline
\end{tabular}

Note: ${ }^{*}, * *$, and $* * *$ indicate that the adjacent industries had identical scores relative the assessment criterion in question. 


\section{Conclusions}

AHP and the FMCDM model are an effective means of converting specialists' qualitative assessments into quantitative indicators, and enable the cross comparison of different criteria and industries. The following is a summary analysis of this study's findings: First, the members of the specialists committee consistently felt that the most important characteristics of an internationally competitive target industry are "marketing channel capability" (first place) and "R\&D \& innovation capability" (second place) under the aspect of "industrialization capability"; the next most important characteristics were considered to be "completeness of relevant laws/certification" (third place) and "degree of domestic industrial policy support" (fourth place) under the aspect of "policies and laws." Second, this study provides each industry a performance report with regard to the different assessment criteria, which will help determine which infrastructure items require improvement. Since many of the target industries are dissatisfied with the condition and performance of the legal environment, this aspect urgently requires improvement if Taiwan's AgBio industries are to develop smoothly. Third, this study's greatest contribution lies in its having brought together experts, industry representatives, and specialists in various AgBio fields for the first time under the "National Science and Technology Program for Agricultural Biotechnology" to discuss industry items encompassing agriculture, forestry, fisheries, and animal husbandry; plants and animals; and products, services, and up- and downstream system integration to facilitate selection tasks. The study placed balanced emphasis on the specialists' subjective judgment and objective assessment of each industry's overall performance relative to all assessment criteria. The resulting information allows the comparison of each industry's level of development and in-depth analysis of the various industries.

While the participating specialists made only a one-time selection, it would be extremely difficult to account exhaustively for all industry items, and sufficient manpower was ultimately not available. As a consequence, this study relied on the specialists' self-assessments of their familiarity towards each of the target industries to ensure that they were qualified to make professional assessments. The study further employed multi-group cross analysis in order to objectively express the specialists' industry performance scores. It is hoped that the results of this study will provide guidance to high-level decision-makers in industry, government, academia, and the research community. Finally, apart from this study's very successfully combined application of AHP and fuzzy theory, it should be mentioned that the assessment criteria took into consideration the theory of industry value chains and industry core competitiveness, etc., and reflected the influence of economic, social, and policy/legal factors. In addition, an effort was made to perform a rigorous, all-round assessment of scientific, economic, and social benefits. As a result, the study's findings may serve as a reference for the drafting of AgBio development strategies in other countries.

\section{References}

Bellman, R.E. and Zadeh, L.A.(1970) “Decision making in a fuzzy environment,” Management Science, $17,141-146$.

Bohanec, M., Zupan, B. and Rajkovic, V. (2000) “Applications of qualitative multi-attribute decision models in health care,” International Journal of Medical Informatics, 58-59, 191-205.

Saaty, T.L. (1977) “A scaling method for priorities in hierarchical structures,” Journal of Mathematical Psychology, 15, 234-281.

Tang, M.T. and Tzeng, G.H. (1999) “A hierarchy fuzzy MCDM method for studying electronic marketing strategies in the information service industry,” Journal of International Information Management, 8, 1-22.

Teng, J.Y. and Tzeng, G.H. (1996) "Fuzzy multicriteria ranking of urban transportation investment alternatives," Transportation Planning and Technology, 20, 15-31.

Zadeh, L.A. (1965) “Information and Control,” Fuzzy Sets, 8, 338-353.

Zadeh, L.A. (1975) "The concept of a linguistic variable and its application to approximate reasoning, Parts 1, 2, and 3,” Information Science, 8, 199-249, 301-357, 9, 43-80. 